\title{
Cosmic Mysticism: Quest for the Absolute in the Works of Tagore and Sri Aurobindo
}

\author{
Swati Samantaray \\ School of Humanities, KIIT University, Bhubaneswar, Odisha, India \\ E-mail: swati.sray@gmail.com
}

Received: 02-08-2016

Published: 02-01-2017
Accepted: 08-10-2016

doi:10.7575/aiac.ijalel.v.6n.1p.298
Advance Access Published: November 2016

URL: http://dx.doi.org/10.7575/aiac.ijalel.v.6n.1p.298

\begin{abstract}
Cosmic mysticism is an immediate experience of oneness with God by means of ecstatic and wordless contemplation. The Indian Renaissance poets Rabindranath Tagore and Sri Aurobindo are spiritual humanists who believe that the entire creation is pervaded by the presence of God. Their exceptional minds have an instinctive urge to synthesize and transform, transmute and transcend the aspects of reality. They regard humans as a replica of the Divine Spirit and hence they value man's ideals and aspirations. Their ways of depicting this is very different, albeit their works bear an analogous thematic purpose, which is cosmic mysticism. This paper delineates the perception of cosmic mysticism in the works of Tagore and Aurobindo. The central theme of their writings - the spiritualization of earthly life - rests on their beliefs that God exists in all of Nature and that spiritual intuition makes it possible for every individual to become conscious of their own divinity. The poets display the cosmic trinity of mind, body and soul in their works and are committed to achieving cosmic consciousness and social amelioration.
\end{abstract}

Keywords: Mysticism, Divine, spirituality, nature, love, philosophy, inspiration, humanism

\section{Introduction}

Cosmic mysticism is the experience of the Divine immanence, the isness of the omnipresent, eternal spirit in all things, and all things in it. All poetry may be considered as an endeavour to express relation of the human beings to the circumambient universe, only aspects may differ. Cosmic mysticism, as we know, is an immediate experience of oneness with God by means of ecstatic and wordless contemplation. In other words, the mystic tries to attain absolute oneness with God by transcending the senses, by becoming more contemplative. The literary figures, Tagore and Sri Aurobindo (who were contemporaries) are still read and re-read with love and admiration; but the association between the two legends has been too insufficiently explored. This paper intends to shed light on the concept and perception of 'cosmic mysticism' in the works of Tagore and Aurobindo. A modest attempt has been taken to identify the moments (which come like flashes), when their soul has touched the Infinite and has become intensely conscious of it through illumination of joy. The entire poetic life of Tagore as well as Sri Aurobindo is a testimony of what Carl Sandburg expressed in The People, Yes (2015), "the endless yearnings of man for the Beyond". They desired to build a world where harmony and understanding reigned over hatred and hostility. Romanticism of these Indian poets is fraught with nationalism, spirituality and mysticism. The two poets were romantics and naturally they were drawn to poets like Keats and Shelley. Both considered poetry as a mode through which the Absolute Power is revealed. Tagore and Aurobindo differ in their poetic approach - the former belongs to the world of actualities, while the latter to the world of supra sensuous realities. Their ways of depiction and their symbolism vary, however their works bear a similar thematic purpose, which is mysticism. Mystic poetry ordinarily defies attempts at analysis or description. Yet Tagore and Aurobindo have chosen to attempt the impossible and their utterances prove intuitive and revelatory.

\section{Tagore: The Myriad - Minded Man}

Rabindranath Tagore (1861-1941) was the envoy of Indian culture to the rest of the world. Tagore was not only the first Indian, but also the first non-European to win the Nobel prize in Literature in 1913. As a poet and a philosopher he has noted that humans have a feeling that they are truly represented in something which exceeds them. The longing for afar, quest to attain the inaccessible, search for the ideal heart's compassion and the longing to know the unknown are some common features found in the poems of this Indian Renaissance poet. The main bulk of his poetry is suffused with a mystical glow. The theism of the Bhagavad Gita, the metaphysics of the Vedas and the Upanishads, the mysticism of the Bauls and the philosophical principles of Vaishnavisim and Sufism exist in synthesis in the works of Tagore. He was also influenced by the English Romantic poets, most notably Shelley. Shelley's "The desire of the moth for the star and night for the morrow" and his "we look before and after/and pine for what is not", for instance, have mystical and transcendental gleams which is not very different from Tagore's mystical utterances. V.S.Naravane points out in his book, An Introduction to Rabindranath Tagore: 
All sides of human nature found full expression in his art. The noble idealism of the Upanishads, the compassion and wisdom of the Buddha, the rationalism of western thought, the love of the Vaishnavas, the humanism of Jesus, the inwardness of the great mystic poets of all ages and countries: everything had its place in Rabindranath's world view and his way of life (1977).

Regardless of the fact that Tagore received inspiration from diverse sources, his notion or perspicacity of religious conviction is perceptible in the following lines:

$$
\begin{aligned}
& \text { My religion is essentially a poet's religion; its touch comes to me } \\
& \text { through the same unseen trackless channel as does the inspiration } \\
& \text { of my music (The English Writings of Rabindranath Tagore, 1994). }
\end{aligned}
$$

He is not satisfied with subjective meditation (that is, he does not reject the finite in the attainment of the Infinite), but wants to realize the Creator in his creations. In Tagore's verses the poetic, philosophic and religious sentiments are moulded into one to occasion "the mystic lyrics of the Bhakti tradition of India" (G. Ignatius, 1961). His mysticism flows into poetry, his poetry bathes in mysticism. In Gitanjali the mystic poet presents the Divine as the great affirmation, the fountain of energy, the source of life and death, and also the belief of the Vedantic doctrine Tat Twam Asi - a Sanskrit statement meaning "Thou Art That", showing the relationship between the individual and the Absolute.

\section{Sri Aurobindo: The Anglophile Rishi}

In the realm of spirituality, Sri Aurobindo (1872-1950) remains an enigmatic Indian personality and philosopher. He is the visionary of a new world order. He may be called the most radical spiritual master ever, who challenged not only perceptions and theories but also our very idea of reality. Aurobindo's integral vision of life and spirituality, his theory of evolution of not only consciousness but matter as well, place him at the head of cutting edge thinkers of all time. His life is "a glorious chronicle of progress from patriot to poet, yogi and seer" as M. K. Naik epitomizes (1982). He has produced monumental works on the Veda, the Bhagavadgita and on Yoga and has presented the philosophy of the Upanishads in a new light, and in all its integrality and depth. Poetry was his passion besides spiritual seeking. His works reveal a wonderful unison of orient and occidental learning. If Sri Aurobindo is known to the world, it is for his philosophy of Integralism as expounded in The Life Divine, wherein he has presented a synthetic view of Western rationalism and Indian spiritualism.

\section{The Nature of Perception and Cosmic Reality}

The two Bengali poets, Tagore and Aurobindo, were brought up in different backgrounds. They were born when India was still under British colonial rule. Bengal was the cradle of the Indian Renaissance during the period in which they were born; it was an era of stress and strain and a period of transition as well. Sri Aurobindo's formal education was entirely western. He was educated in England and was proficient in Greek, Latin and English. Tagore had his early education at home and then went to England to study law. Unlike Tagore, who wrote most of his works originally in Bengali and later translated them into English, Sri Aurobindo has all along expressed himself in English. Both were brought up in an atmosphere of colonial opulence. Tagore and Aurobindo were polar opposites on the issue of nationalism. In other words, Rabindranath was not a political person in the sense that Aurobindo was. He did not enter into the vortex of politics as his compatriot did; but that did not prevent him from raising his voice against the social and political injustice of the British rulers. The sufferings of the Indian people moved him to political action at every critical stage of the national struggle. He became the spokesperson of the Swadeshi movement in 1906. He protested against the violence at Jalianwalabagh in 1919 and again in 1920, during the non-cooperation movement, he disapproved of certain aspects of the national political problem. Tagore was knighted by the ruling British Government in 1915, but he resigned the honour as a protest against British policies in India. The deep humanism and the religious fervour which coloured his political attitude and belief is best seen in the song he wrote for a session of the Indian National Congress. After independence, India chose Jana Gana Mana Adhinayaka (which can roughly be translated as 'the leader of people's minds') as its national anthem. Aurobindo played a significant role in the Anti-Partition movement. During his stay at Cambridge, he came in contact with a revolutionary organization known as the Indian Majlis. Later on he joined another secret society called 'Lotus and Dagger' to uplift India. He saw a very intimate affiliation between spirituality and politics (which he recorded in the editorial of 16 November 1907):

Nationalism is an avatara and cannot be slain. Nationalism is a divinely appointed sakti of the Eternal and must do its God-given work before it returns to the bosom of the Universal Energy from which it came.

(Aurobindo, in Iyengar 1950)

He treated national independence as a means to provide spiritual leadership to the world. He wanted India to be free and promote the material welfare of the people and occupy an honoured place in the community of nations, with a view to ensure that her ancient spirituality should triumph and may become a guiding light to the whole of the human race. He opined that humans must evolve beyond the super mind eventually leading to the emergence of a new race of beings: 
He (Aurobindo) argues that Asia and particularly India may be materially backward than Europe, but it possesses the secret of human maladies. He adds that India has to rediscover the secret of human truths found in Vedanta and teach them to humanity... According to him, India can show the world the true source of human liberty, equality and brotherhood (Kapoor, 1991).

Thus while Tagore highlights the imperative importance of the freedom of India for the purpose of ensuring world peace, Aurobindo asserts that there could be no solution of human problems without the freedom of India.

Both the spiritual humanists believe (though Aurobindo is 11 years younger than Tagore) that education must touch the lives of people in entirety, that is, social, economic, spiritual, and intellectual. They lay emphasis on the freedom in education - education that crafts our life in concord with all existence. As Shantiniketan grew with Gurudev Tagore, so grew Pondicherry Ashram with the Mahayogi Sri Aurobindo (with Mother, his spiritual collaborator). Tagore pleads for an education which would lead to a well-integrated development of the human personality. The harmonious relationship of human beings and nature was the central theme in his vision of an educational curriculum. Sri Aurobindo too feels that it is important to set educational institutions in natural environment so that the learner can learn by their touch with Nature. He also placed emphasis on the all-round development of the personality, which included education of the body, mind and senses, as well as moral and spiritual education. They cherished man's ideals and aspirations and considered humans to be a replica of the Divine Spirit. Tagore saw education as a process that ensures the possibility of eternal progress. Indian thought, as expressed in the educational philosophy of Tagore, stresses on a comprehensive education aimed at the development of the total personality of the individual, in harmony with nature and society.

Tagore founded Shantiniketan where educational pattern was reformed to create a bond between knowledge and the nature. He accepts Nature as a melody of God which ennobles human beings. In the "Introduction" to Banabani (The Message of the Forest), Rabindra Rachanavali, volume 8, Tagore provides a philosophical outline of his approach to Nature:

The language of Nature is the eternal language of creation. It penetrates reality to reach the deepest layers of our consciousness (1986).

As Dr. S. Radhakrishnan points out in The Philosophy of Rabindranath Tagore:

"...Rabindranath advocates life in nature and in the open as the best means of spiritual progress, for in nature the religious eye will see the infinite lying stretched in silence smiling repose. According to him the best way to derive inspiration is to lose oneself in the contemplation of nature..." (1992).

Like Tagore, Aurobindo too is a great lover of Nature. The most significant contribution of Sri Aurobindo to education is Auroville - a city of universal culture. The environment of Auroville was organised with the aim of humanising the people by synthesizing their ideologies, knowledge and culture. Purusha and Prakriti for Sri Aurobindo are inseparable and they are the twin aspects of the one indivisible Absolute. Santosh Krinsky speaks about Sri Aurobindo's concept of oneness of creation thus:

"Not only is there an obvious continuum here which places the human being squarely in the midst of the evolutionary process of the world, but there is also a clearly symbiotic relationship that makes it impossible for the human being to live without the environment and the other beings in the environment to support, nurture and create the conditions needed for our existence. We require oxygen to breathe, and plants create oxygen. We have beneficial bacteria in our intestines that are important to our digestive process. Our skin creates an essential vitamin from sun rays. The entire creation is One and unified and depends on each part to manifest the whole" ( 2013).

Tagore's love for Nature differs from that of Sri Aurobindo in degree:

Every poet of Nature has felt some affinity with her but none has felt so deeply as he the inseparableness with Nature. No poet has been able to efface his separate identity and merge completely into the vaster life of Nature as Tagore has done" (B.C. Chakravorty, 1971).

According to the critic Mohit Kumar Ray, in Aurobindo we find total manifestation of spiritual experience, but Tagore does not sacrifice the poetry at the altar of spirituality - his poetry is fusion of poetry and mystic feelings.

Each object of nature and every form of life is an expression of the Divine. In Tagore's poetry, child occupies a unique place. The paedotrophic imagery in The Crescent Moon is perhaps unique in world literature. Sri Aurobindo too has high esteem for a child. A child's state of mind is like a yogi who absolutely satisfied with his own realm of Paramananda. A child whose fancy is pure and chaste always sees God through his power of innocence. In his poem 'The Child's Imagination', Aurobindo writes:

O thou golden image

Miniature of bliss... (1972) 
The poets found in children innocence, beauty, humour, charity and also the traits of a mystic. According to Tagore, God sends us sufferings out of his love for us, as pain and sorrow purify the soul. Adversity and agony of the humankind are the opportunities employed by God to draw man's consciousness to his real destiny.

5. Tagore And Aurobindo: A Quest For Cosmic Mysticism

In Sadhana Tagore writes: "The oneness between the Divine Reality and the individual self is established through perception. The vision of the Supreme One in our own soul is a direct and immediate intuition, not based on any ratiocination or demonstration at all " (2006). The Upanishads also speak of the immanent Brahman, the Supreme Reality which is an all suffusing force that transcends comprehension and any sort of description. The Hindu idea is that all things in the cosmos, even the famous Hindu deities, are only temporal manifestations of the Brahman.

There is no denying the fact that the poetry of Tagore and Aurobindo is energized by their mystic consciousness. Rabindranath begins as a romantic poet and in his imaginative flights he tries to discover his spirit. Aurobindo too in his lyrics describes God as a vision or presence. He can be felt on the physical and material planes. The poems like Revelation, The Blue Bird, The Inner Sovereign, Liberation, Immortality, Epiphany, Shiva, Surrender, Because Thou Art (all included in his Collected Poems) set the evolutionary process, which got fruition later, thus paving the way for rhythmic insight into values and significant possibilities in his epic poem Savitri:

The bounded mind became a boundless light

The finite self mated with Infinity

Above mind's twilight and life's Star-led night

There gleamed the dawn of spiritual day.

(Aurobindo, 1995, pp.25-26)

In Savitri, Sri Aurobindo records his inspiration, revelation, intuitive judgement and intuitive reasoning, thus expounding his philosophy - the stairway of ascension on to the supramental light from the unfathomable Darkness of the Inconscience, descent of supramental force and consciousness for the divine transformation of all mankind and earth-consciousness. The seer-poet predicts: 'All can be done if the God touch is there' (Book I, Canto 1: 4-5, 1995).

Tagore's mystic voyage can be understood in four distinct phases. In the first stage he had the vision of the Infinite in the finite. This experience is revealed in his works such as Kori-o-Komol (Sharps and Flats) and Prakritir Pratishodh (Nature's Revenge). The second stage of Tagore's mystic journey is marked by his quest for Jibandebata, embodied in poems like Manasi, Sonar Tori and Chitra. The third stage is the stage of devotion. This stage produced poems like Gitanjali. Other poems of this stage are Naivedya, Gitimalya, Stray Birds and Balaka. The last stage of Tagore's mystic journey finds expression in The Gardener, The Crescent Moon, Hundred Poems of Kabir, Fruit Gathering, Lover's Gift, Crossing, The Fugitive, and Poems of 1942. Tagore has recorded that mystical moment in Jivan Smruti or Reminiscences:

"One morning I happened to be standing on the verandah looking that way. The sun was just rising through the leafy tops of the trees. As I gazed, all of a sudden a lid seemed to fall from my eyes, and I found the world bathed in a wonderful radiance, with waves of beauty and joy swelling on every side ... That very day the poem 'Nirjharer Swapnabhang' gushed forth and coursed on like a cascade" (1991, pp.153-154).

What Tagore sought is the perfect union where and when heaven and earth, time and space, pleasure and pain, death and life integrate together in an unbearable ecstasy. Therefore, the yearning: 'I want thee, only thee' (Gitanjali, poem number 38, 1912, p.36), which led time and again to flashes of the mystical height:

"You have come, Radiant One, You have broken upon the door

May Victory be yours...

Victorious Hero, with the dawn of a new day...

Let my bondage break,

Victory be yours". (A Tagore Testament 1953, p.67)

Sri Aurobindo's life is a saga of psychic experiences. Some such experiences are - the lifting of an enveloping darkness while he was returning to India, a deep sense of inner peace that descended on him as soon as he put his foot on the soil of India (Apollo Bunder in Bombay), the experience of the vacant Infinite in Kashmir (Takht-i-suleman or Hill of Shankaracharya), the experience of a presence and a power in the shrine of Goddess Kali in a temple on the bank of the Narmada, the experience of finding thoughts entering from outside and flowing out as speech after the Surat Congress in 1907, the vision of Krishna or Narayana in Alipore jail and the epoch making realization in 1926 - are the turning points of his life. The central theme of his vision is the evolution of human life into life divine. He envisaged a world union where the entire humanity could exist in peace, harmony and unity. He thought of poetry as sadhana yantra for achieving the life divine or in other words we may say, poetry for him was a part of sadhana, "a means of contact with the divine through inspiration" (The Future Poetry 1971, p.504). Both Tagore and Aurobindo integrate the Western 
philosophy with the Indian one. We find an amazing similarity between the vision of Tagore and Aurobindo - they believe that Beauty is the Soul's path to the Supreme Divine Reality. For Sri Aurobindo, beauty, mysticism and music are parts of his all-inclusive Supramental consciousness. Tagore says in Sadhana, "the true poets, they who are seekers, seek to express the universe in terms of music ". With reference to "The Sources of Poetry" (The Harmony of Virtue 1972, p.102) we can say that Sri Aurobindo treats poetry as an act of inspiration that is born out of an experience of the ideal vision of the Absolute. Hence it is paradigmatically redemptive. This ideal redemptive imagination penetrates the very heart of humans. This signifies that poetry is the vision of the Divine. Sri Aurobindo says that imagination/inspiration is in reality 'a revelation' (The Harmony of Virtue 1972, p.105). Consequently, the poet becomes an inspired medium through whom the abstract imagination gets a concrete verbal form. This view of Sri Aurobindo is reinforced in his The Future Poetry which expounds his theory of poetry. The poet-critic says thus:

"The voice of poetry comes from a region above us, a plane of our being above and beyond our personal intelligence, a Supermind which sees things in their innermost and largest truth by a spiritual identity and with a lustrous effulgency and rapture and its native language is revelatory, inspired, intuitive word limpid or subtly vibrant or densely packed with the glory of this ecstasy and lustre" (1971, p.298).

Sri Aurobindo uses the term mantra to refer to the highest form of poetry. He conceptualized poetry as the "Mantra of the Real". Mantric imagination makes us to see to the nature of things and to purge ourselves off the taints which sully human soul. The Gita has made a deep impact on the thoughts of Aurobindo which can be seen in his elaborate commentary on it in the two volumes of his Essays on Gita.

Yoga, for Sri Aurobindo, is the activity of finding the Divinization of the humankind. His integral yoga is said to be based on three stages of concentration. Firstly, the attempt of the human ego to establish a contact with the Divine, that involves the transformation of the lower nature into higher nature. The second phase is the process of locating the Divine in the human body. The final stage is the eventual transformation of the human into the Divine. Sri Aurobindo's yoga is a synthesis of all other yogas termed purna yoga. As a mystic poet Gurudev Rabindranath had no patience with yogic method of cultivating mystic consciousness. Literature and music were his vehicles, that took him to the world of the infinite beauty and love. The songs of Tagore (termed Rabindra Sangeet in original Bengali) sing of the man-God relationship which takes a number of forms, friendship (sakhya), service (dasya), love (prema), and so on. Mysticism is another aspect of this relationship. He conceives of the divine nature of the finite souls who come in communion with God and have their own existence and individuality. For Tagore, God is Satyam, Shivam and Sundaram, that is, Truth, Goodness and Beauty. He feels that there exists a personal relationship between God and man. Love, music and poetry are the means to come closer to God and thereby to remain in continuous communion with Him.

The mystic-poets discuss about the relation between the Finite and the Infinite, which is one of interdependence. Tagore refers to the Ultimate Reality as Jivandevata, while Aurobindo refers to the Ultimate Reality as Sachidananda. Both the poets talk about the goal of human life as being the oneness of the Finite and the Infinite. Tagore believes that the fundamental principle of life is not an abstract principle as science might believe; it is a creative principle out of which everything has taken and has been taking its rise. Nevertheless, "the human body is the temple of the soul, the human soul is the temple of God. The human soul is nought unless it is inhabited or 'filled' by the Spirit. Birth and death are but the filling and the emptying of the soul by the Spirit, and the individual - insignificant as he may seem to be - verily partakes of God's endless life, His immortality"(Iyengar, 1950). He feels love alone is the meeting point of the finite and the Infinite:

God kisses the finite in His love

and man the Infinite.

(Tagore in Stray Birds, poem no. 303, 1916)

Life for Tagore is an unceasing pilgrimage that meets the finale with death:

I shall die again and again to know that life is inexhaustible.

(Stray Birds poem no. 282)

For him love leads to joy, which is, in a sense, "the realization of oneness, the oneness of our soul with the world and the world-soul with the Supreme Lover". He commented thus: "the fundamental unity of creation was not simply a piece of philosophical speculation for India, it was her life-object to realize this great harmony in feeling and in action"(Sadhana 2006, p.116). For a religious poet, like Tagore, Love is essential to everything. Through the beauty of this universe, through the loveliness of our dear ones, it is ultimately God, the all pervading One, who is ever drawing us to Himself.

"The joy ran from all the world to build my body,

the lights of the sky kissed and kissed her till she woke.

Flowers of hurrying summer sighed in her breath and

voices of winds and water sang in her movements. 
The passion of the tide of colour in clouds and in forests

flowed into her life and the music of all things

caressed her limbs into shape.

She is bridle, she has lighted her lamp in my house".

(Tagore in Fruit Gathering poem no.72, 1916)

The theme of God-love is also represented in the following lines:

"Where is this hope of union except in Thee, my God".

(Tagore in The Gardener poem no.50, 1912)

Love for Sri Aurobindo is a sign from Heaven, assuring humans of their divine origin and destiny:

"Love must not cease to live upon the earth;

For love is the bright link twixt earth and heaven,

Love is the far Transcendent's angel here;

Love is man's lien on the Absolute".

(Savitri Book 10, Canto3, pp.632-633)

The union of Satyavan and Savitri represents the virtue of total love. In fact, the love between Savitri and Satyavan is the love between "a little figure in infinity" and "God's Living Reality".

Mysticism is a journey from being to becoming. The intensity of the experience and the shift in consciousness is beyond the grasp of language. There is no formula for correlating mystical experiences with ordinary language. 'Glimpse into reality' are often unique and hence inexpressible. The relation between the Absolute, infinite, and immutable and the finite human individual who is enmeshed in the temporal order is unimaginably intimate though difficult to define and explain. Since the mystic poets are inspired by divinity, they feel an overwhelming urge to fashion a piece of utter and unsurpassable poetry. So symbolism constitutes an essential and dominant feature of their poetry. Both Tagore and Sri Aurobindo have expressed the mystical oneness with the Absolute making use of symbols and images. The symbolic treatment in their works clearly reveals the search for spiritual identity. Tagore unites his voice with Aurobindo when he says:

Man is true, where he feels his infinity, where he is divine, and the divine is the creator in him. Therefore with the attainment of his truth he creates. For he can truly live in his own creation and make out of God's world his own world....If man could only listen to the voice that rises from the heart of his own creation, he would hear the same message that came from the Indian sage of the ancient time: 'Hearken to me, ye children of the Immortal, dwellers of the heavenly worlds, I have known the Supreme Person who comes as light from the dark beyond (G.N. Devy, 2002).

\section{CONCLUSION}

Cosmic mysticism is the manifestation of the divinity in humans, as well as the reconstruction of an individual's entire physical, social, economical, political, and cultural environment by the transforming power of the Divine. Both Tagore and Aurobindo represent the selective assimilation of modernity. Their luminous words remain ever fresh. Tagore was touched by the soul stirring writings of Sri Aurobindo. He called on Aurobindo and read out to him his heart's homage, of which the opening lines are:

\section{Rabindranath, O Aurobindo, bows to thee! \\ $\mathrm{O}$ friend, my country's friend, $\mathrm{O}$ voice incarnate, free. \\ Of India's soul! (Salutation)}

[The original Bengali was first published in the Bande Mataram on September 8, 1907. The English translation done by Kshitish Chandra Sen was first published in the Sri Aurobindo Mandir Annual, Calcutta, 1944]

On Tagore's literary genius, Aurobindo says, "... His work is a constant music of the over passing of the borders, a chant-filled realm in which the subtle sounds and lights of the truth of the spirit give new meanings to the finer subtleties of life" (Future Poetry 1971, pp.321-323).

If poetry is the language of imagination, cosmic mysticism is Imagination itself, the unlimited, eternal thing at which poetry hints. Both the poets express their intense spiritual experience in their multiple-nuanced poetry. Gurudev Rabindranath Tagore and Sri Aurobindo were the modern spokespersons of universalism, humanism, and of the oneness of human beings. They feel that the entire creation is said to be pervaded by the presence of God. Their gifted minds have an instinctive urge to synthesize and transform, transmute and transcend the aspects of reality. The central theme of their writings - the spiritualization of earthly life - rests on their beliefs that God exists in all of Nature and that spiritual intuition makes it possible for every individual to become conscious of his own divinity. "The goal [of 
cosmic mysticism] is to develop a mature identity by establishing a true self; a responsive identity designed to transcend the natural patterns and restrictions so we can move into our future with greater intention and freedom" (Laveman, 2006). A healthy humanity should be based upon a cosmic unity.

\section{References}

Aurobindo. (1995). Savitri: A Legend and a Symbol. USA: Lotus Press, pp. 25-26. . (1971). The Future Poetry. Pondicherry: Sri Aurobindo Ashram.

- (1990). The Life Divine. Pondicherry: Sri Aurobindo Ashram.

. (1972). Collected Poems. Sri Aurobindo Birth Centenary Library. Vol. 5.

(1972). "The Sources of Poetry", The Harmony of Virtue in SABCL, Vol. 3, Pondicherry: SAA, p. 102.

Badrinath, D. (2015). Divine Love and Joy in Rabindranath Tagore's Gitanjali: A Journey to Self-Knowledge. Chennai: Notion Press.

Chakravorty, B.C. (1971). Rabindranath Tagore - His Mind and Art. New Delhi: Young India Publications, p. 45.

Cornelissen, R.M., Matthijs, Girishwar, M., \& Suneet, V. (2011). Foundations of Indian Psychology. Delhi: Pearson Education India, p.159.

Das, Sisir Kumar ed. (1996). The English Writings of Rabindranath Tagore, vol. II, New Delhi: Sahitya Akademi. Devy, G. N. (Ed.). (2002). Indian Literary Criticism: Theory and Interpretation. Hyderabad: Orient Longman, p.149. Dutt, Indu Ed. \& Tr. (1953). A Tagore Testament. London: Meridan Books.

Ghosal, G. (2007). The Rainbow Bridge. New Delhi: D.K. Printworld.

Grover, V. (1993). Sri Aurobindo Ghose. Delhi: Deep \& Deep Publications.

Gupta, N.K. (1970). Seer Poets. Pondicherry: Sri Aurobindo Ashram.

Ignatius, G. (1961). All Mine, My True Love, and I All His. In The Proceedings of Indian Philosophical Congress, 36th Session, published by Rabindranath Tagore Birth Centenary Celebrations, Visva-Bharati, p. 216.

Iyengar, K. R. Srinivasa. (1950). Indian Writing in English. New Delhi: Sterling Publishers Private Limited, p. 211. James, G.A. (1999). Ethical Perspectives on Environmental Issues in India. New Delhi: APH Publishing Corporation. Kapoor, S. (1991). Sri Aurobindo Ghosh and Bal Gangadhar Tilak: The Spirit of Freedom. New Delhi: Deep \& Deep Publications, p.65.

Krinsky, Santosh. (2013). Readings in Sri Aurobindo's Rebirth and Karma. Lotus Press, p.50.

Laveman, Larry. (2006). Mysticism and Modern Life. California: Metall Press, p.11.

Mohanty, Bindu. From Man to Superman. https://www.lifepositive.com/from-man-to-superman/ Retrieved on 30 October 2015.

Murali, S. (1997). Mantra of Vision: An Overview of Sri Aurobindo's Aesthetics. Delhi: B. R. Publishing Corporation.

Naik, M.K. (1982). A History of Indian English Literature. New Delhi: Sahitya Akademi, p.47.

Nanda, R.T. (1997). Contemporary Approaches to Value Education in India. New Delhi: Regency Publications. Pp 202-220.

Naravane, V.S. (1977). An Introduction to Rabindranath Tagore. Delhi: Macmillan, p.9.

Prasad, Amar Nath \& Rajiv K. Mallik. (2007). Indian English Poetry and Fiction: Critical Elucidations. New Delhi: Sarup \& Sons.

Patel, A. (2002). Perspectives on Sri Aurobindo's Poetry, Plays, and Criticism. New Delhi: Sarup and Sons, p.7-8.

Radhakrishnan, S. (1992). Rabindranath Tagore: A Centenary Volume 1861-1961. New Delhi: Sahitya Akademi, p.21. (1918). The Philosophy of Rabindranath Tagore. London: Macmillan.

Roy, R.N. (1992). Rabindranath Tagore: The Dramatist. Calcutta: A. Mukerjee \& Co.

Samantaray, S. (2013). Demystifying Mysticism: A Comparative Study of the Poetry of William Blake and Rabindranath Tagore. 3L:The Southeast Asian Journal of English Language Studies, 19(2), pp. 41-51.

Shelley, P.B. (1993). Selected Poems, Canada: General Publishing Company.

Sandburg, Carl. (2015). The People, Yes. London: Houghton Mifflin Harcourt, p. 285.

Tagore. (1912). Gitanjali, London: Macmillan \& Co. (Subsequent references are from this edition) .(2006). Sadhana. USA: Filiquarian Publishing.

(1922). Poems from Tagore. Calcutta: Macmillan \& Co.

(1916). Stray Birds. New York: Mcmillan \& Co.

(1916). Fruit Gathering. London: Mcmillan \& Co.

(1912).The Gardener. London: Macmillan \& Co.

(1991). My Reminiscences. intro by Andrew Robinson. London: Mcmillan Publishers Limited, p.153-154.

(1994). The English Writings of Rabindranath Tagore : A Miscellany. Vol.3. New Delhi: Sahitya Akademi,

p.688.

(1986)."Introduction" to Banabani, Rabindra Rachanavali, Vol.8. Kolkata: Visva Bharati, p. 87.

Tagore, R., \& Mohit, K.R. (2007). The English Writings of Rabindranath Tagore. Vol.4. New Delhi: Atlantic Publishers, pp.356-357.

Varma, V.P. (2006). Philosophical Humanism and Contemporary India. Delhi: Motilal Banarsidass Publishers. 